\title{
Je to o fenomenálním charakteru
}

\author{
Michal Polák \\ Fakulta filozofická \\ Západočeská univerzita v Plzni \\ Jungmannova 1, 30614 Plzeň \\ miha@kfi.zcu.cz
}

\begin{abstract}
Argumentace Tomáše Hříbka proti fenomenálnímu charakteru se opírá především o Dennettova stanoviska. Dennettem dlouhodobě preferovaná strategie při vypořádání se s tímto problémem je metodologický naturalismus. Tato strategie jistě přinesla své ovoce, zejména je-li řeč o otevření skutečně kritické diskuse na téma kválií. Problém vědomí je však v současnosti traktován spíše v rámci materialistické metafyziky, než z pohledu Dennettova metodologického naturalismu. Tato preference má své empirické, ale i filosofické důvody, o nichž jsme hovořili s Tomášem Marvanem v knize Vědomí a jeho teorie. Protože Hř́ibkova monografie reaguje na některé názory z této knihy, komentuji Hř́bkovy reakce a upřesňuji naše postoje. Zároveň se vyjadřuji k zařazení naší pozice $\mathrm{v}$ rámci materialistické metafyziky k materialismu typu B. V druhé části statě se zabývám problémem fenomenálního charakteru vědomé zkušenosti a snažím se argumentovat, že tento těžký problém nelze odstranit pouze tím, že se prokáže neudržitelnost tradičního chápání kválií.
\end{abstract}

\section{Úvod}

Ve své mimořádně obsáhlé knize Jaké to je, nebo o čem toje: Místo vědomí v materiálním světě ${ }^{1}$ se Tomáš Hříbek věnuje tradičním filosofickým aspektům lidské mysli. Zejména staví do kontrastu problém intencionality a otázku vědomí. Domnívá se, jako ostatně většina filosofư mysli, že tyto dva problémy jsou traktovatelné oddělitelně, ale jde ještě dále. Pokud se nemýlím v porozumění knize, Hříbek má za to, že problém vědomí, přesněji řečeno jeho fenomenální stránku, lze zredukovat na problém intencionality. V širším slova smyslu jde o to, že charakter všech

1 Hř́bek (2017). 
vědomých mentálních stavů je vymezitelný čistě s pomocí reprezentačních vlastností těchto stavů. Pokud by tomu tak bylo, pak by se i ony tak problematické fenomenální vlastnosti vysvětlily jakožto reprezentační vlastnosti mentálních stavů, př́padně vlastnosti reprezentovaných entit. $\mathrm{K}$ diskusi je zde jistě řada témat; dvěma $\mathrm{z}$ nich budu věnovat bližší pozornost. Protože se ale v Hříbkově monografii píše o knize Vědomí a jeho teorie (2015), kterou jsme napsali s Tomášem Marvanem, vyjádřím se nejprve $\mathrm{k}$ těm úryvkům, které zmiňují naše názory na vědomí. $\mathrm{V}$ druhé části statě bych se rád soustředil na to, $v$ čem se lišíme, pokud jde o názor na Dennettův přístup k fenomenálnímu vědomí. Rád bych předeslal, že $\mathrm{v}$ této části textu vyjadřuji především své názory, a je tudíž možné, že některé z nich by Tomáš Marvan nesdílel. ${ }^{2}$

\section{Materialismus typu ...}

Jedna $\mathrm{z}$ věcí, která mě v neformálních diskusích $\mathrm{s}$ Tomášem Hříbkem k jeho a k naší knize zaujala, bylo jeho tvrzení, že jakožto zastánci teorie identity se pravděpodobně přihlašujeme $\mathrm{k}$ materialismu typu $\mathrm{B}^{3}$. V tomto př́istupu není prostor pro karteziánský dualismus, protože podle Chalmersovy klasifikace se jedná o striktně materialistickou pozici. Radikálnější je již jen eliminativismus (v Chalmersově klasifikaci materialismus typu A). Ten bývá obvykle charakterizován jako metafyzická teze, že mentální (psychologické) vlastnosti neexistují a lidově-psychologický diskurz lze zcela eliminovat ve prospěch materialistického popisu mozkových stavi̊ a procesů. Patří-li vědomí do kategorie mentálních vlastností, pak eliminace musí platit i pro něj. Odlišit eliminativismus od materialismu typu B však může být poměrně obtížný úkol, protože většina těch, kteří bývají řazeni do skupiny eliminativistů, tvrdí spíše to, že chybné je naše běžné chápání mysli, ${ }^{4}$ propozičních mentálních stavi̊, 5

2 Děkuji velice oběma anonymním oponentům za důležité připomínky, které jsem se snažil v textu zohlednit.

3 Jde o klasifikaci Davida Chalmerse, v níž rozlišuje šest pozic od striktně materialistických až po radikální dualismus substancí. Mezi nimi jsou různé kompromisní varianty, které více či méně reflektují specifickou povahu vědomí. Viz Chalmers (2010).

4 Feyerabend (1963).

5 Churchland (1981). 
vědomí či kválií, ${ }^{6}$ a nikoli, že by neexistovalo vědomí jako takové. Rozdíl mezi eliminativismem a materialismem typu $B$ tak může být velmi jemný, nebo v podstatě nijaký, jak se domnívá Quine ${ }^{7}$ ve Word and Object. ${ }^{8}$ Je tedy k zamyšlení, zda uvedení autoři nejsou bez potíží zařaditelní spíše do kategorie materialismu typu B.

Vezmeme-li v úvahu „pravé" materialisty typu B, jejich postoje se mohou i diametrálně lišit. Na jedné straně by sem nejspíš patřili tradiční teoretici identity jako Feigl ${ }^{9}$, Lewis ${ }^{10}$, Smart ${ }^{11}$ či Place $^{12}$. Ti sdílejí ideu redukce mentálního na fyzické, nicméně charakter této redukce vysvětlují někdy i velmi odlišným způsobem. Na druhé straně Chalmers řadí do kategorie B Tyea, Lycana, Blocka a Stalnakera či dokonce Rosenthala, což jsou názorově opět značně rozdílní filosofové. ${ }^{13}$ Nechci se zde věnovat důvodům, proč právě tito jsou zařazeni do kategorie materialismu typu B. Pokud ale do této kategorie patř́ teoretici identity, pak do ní pravděpodobně patř́me i my. Zároveň se ale neztotožňujeme s řadou postojů našich kategoriálně spř́izněných kolegů.

Výrazným př́padem filosofa, s jehož názory týkajícími se problematiky fenomenálního charakteru vědomých stavů se v některých zásadních ohledech neztotožňujeme, patří právě Daniel Dennett. Blízká je nám jeho teze, že kvália nepředstavují nějakou neodstranitelnou překážku výzkumu vědomí. Na druhé straně se nám Dennettův názor ${ }^{14}$ na fenomenální obsahy vědomí jeví až př́liš radikální. Podle nás se „Dennett v některých formulacích povážlivě blíží představě, že fenomenální stránky vědomí neexistují, že jsou to iluzorní výplody naší teorie o fungování lidské mysli““. ${ }^{15}$ Vědomí podle Dennetta tak sice existuje, ale nemá žádné pozoruhodné vlastnosti, jako jsou ty fenomenální. My se naopak domní-

6 Rey (1983).

7 Chalmersovu klasifikaci Quine neznal. Jeho stanovisko zde pochopitelně předjímáme na základě dostupných názorů.

8 Quine (1960, 264-265).

9 Feigl (1958).

10 Lewis (1966).

11 Smart (1959).

12 Place (1956).

13 Srov. Tye (1995), Lycan (1996), Block \& Stalnaker (1999), Rosenthal (1997).

14 Např. v Dennett (1991, s. 372).

15 Marvan \& Polák (2015, s. 35). 
váme, že vědomí tyto fenomenální vlastnosti má, přestože jsou uchopitelné v nějakém naturalizovaném typu výkladu.

$\mathrm{V}$ knize se tedy přihlašujeme $\mathrm{k}$ názoru, že vědomí je nositelem fenomenálních kvalit. ${ }^{16}$ Podle Hř́bka by navíc naše pozice byla aposteriorním fyzikalismem, čímž má zřejmě na mysli, že fyzikální povaha světa, v němž existuje i vědomí, není předpokládána jako metafyzická teze, ale je empirickou vědou dokazována. Protože věŕíme v platnost materialismu, je pro nás naprosto zásadní role, kterou při výzkumu vědomí sehrávají empirické vědy. Náš názor v knize se tak skutečně zakládá na tezi, že empirická věda o vědomí je relevantním nástrojem, jak o vědomí zjistit, jak zapadá do řádu přrírody. Zároveň ale netvrdíme, jak nám Tomáš Hříbek přisuzuje, že věda o vědomí má být prostá veškeré filosofické konceptuální práce. Konceptuální práce je nezbytnou součástí vědy o vědomí. Vezměme např́ílad filosofické debaty o tom, jak vymezit pojem „neurálního korelátu vědomé zkušenosti“ ${ }^{17}$ které se nakonec promítají, at přiznaně či nepřiznaně, i do úvah neurovědců o tomtéž tématu.$^{18} \mathrm{Na}$ druhou stranu ale také nevidím důvod, proč by empirický výzkum nemohl rozhodnout některé filosofické kontroverze. Např́klad hledání mechanismu vzniku vědomí má samozřejmě i své filosofické hypotézy, jako je myšlenka vyššího řádu nebo atencionalismus. Neumím si ale představit, jak by filosofie se svými konceptuálními nástroji mohla prověřit, která z těchto hypotéz, pokud vůbec nějaká, je pravdivá. Ostatně je to právě díky empirickým poznatkům, že dnes obecně převažuje materialistický názor o konstitutivní závislosti mysli na mozku. Zároveň ale neř́íkáme ani to, že takové vědě postačí pouhé shromažd'ování empirických výsledků. ${ }^{19}$ Jsem však přesvědčen, že v tomto případě jde spíše o nedorozumění, které pravděpodobně pramení z toho, že přisuzujeme empirickým datům větší váhu, než je přijatelné pro Tomáše Hříbka.

\footnotetext{
16 Na druhou stranu ale netvrdíme, že fenomenální kvality neexistují, absentuje-li vědomí. (Marvan \& Polák 2015). Více k tomu viz níže.

17 Viz Chalmers (2000); Hohwy \& Bayne (2015); Fink (2016).

18 Viz Koch et al. (2016); Frith, Perry \& Lumer (1999).

19 Srov. Hř́ibek (2017, s. 27-28).
} 


\section{Proti kválofilům}

Hlavní kritika naší knihy se však nachází v kapitole Proti kválofilii. Ta obsahuje kromě jiného i naše vymezení kválií, které konstatuje, že jsou to „vlastnosti vědomých stavů, které jim propůjčují jejich specifickou kvalitativní povahu“ “. ${ }^{20} \mathrm{~V}$ knize i jinde používáme pro kvália termín „fenomenální charakter“, zejména proto, abychom se vyhnuli některým tradičním konotacím spojeným s pojmem kvále. Hříbek rozlišuje dva typy kválií - inflační a deflační - a toto naše vymezení považuje za definici deflačních kválií. Inflační kvália představují tradiční vymezení kválií jako niterných, soukromých, nepopsatelných a nekorigovatelných entit. $V$ pojmu deflační kvália rezonuje naopak snaha omezit toto neodůvodněně robustní vymezení, ale zachovat $\mathrm{z}$ něj přinejmenším tu skutečnost, že vnímané entity se ve zkušenosti prostě nějak jeví. Fenomenální charakter vědomé zkušenosti tak zůstává a lze s ním počítat jakožto $\mathrm{s}$ předmětem projektu naturalizace inflačních kválií. Osobně považuji fenomenální charakter vědomé zkušenosti za naturalizovatelný, i když se bude jednat o komplikovaný projekt spojený s intenzivní spoluprací filosofie a empirických věd o vědomí. Podle Tomáše Hř́ibka však žádný takový projekt nebude zapotřebí, nebot podle jeho názoru je pojem fenomenálního vědomí nejen neudržitelný, ale co hůř, je bezobsažný. ${ }^{21}$ Zdá se, že toto je nejradikálnější, ale také nejkontroverznější teze celé knihy. Vzhledem k tomu, že Hř́bkova teze zásadně stojí na pilíríich Dennettova postoje $\mathrm{k}$ fenomenálním kvalitám, budu následující text věnovat oběma autorům.

Hř́bek na začátku knihy vyjadřuje názor, že Dennett sice je materialisticky smýšlející filosof, ale nejde mu o hledání místa vědomí v přírodě, tj. jeho cílem není nalézt prostor pro vědomí v materiálním světě. ${ }^{22}$ Jeho cílem však je zachovat jak lidověpsychologické pojetí naší mysli, tak i obraz, který nám o mysli poskytuje věda. Co se tím ale přesně míní? Zdá se mi, že rozdíl mezi snahou hledat místo vědomí v př́rodě a snahou uvést do souladu výše uvedená dvě pojetí naši mysli nespočívá v ničem jiném,

20 Hříbek (2017, s. 230).

21 Tamtéž, s. 230.

22 Tamtéž, s. 19. 
než v tom, že první přístup předpokládá metafyzické uvažování o vědomí (respektive o mysli) a hledání jeho esenciálních vlastností, které zdánlivě nezapadají do řádu přírody. Cílem naturalistického projektu - a právě tak vidím snahu nalézt místo vědomí v přírodě - pak má být ukázat, že tyto pozoruhodné vlastnosti do přírody zapadají velice přirozeně. Oproti tomu druhý přístup je čistě konceptuální. To, co chce zachovat, jsou dva zdánlivě nesouměřitelné popisy určité části světa. Dennett tak chce dosáhnout harmonické koexistence dvou obrazůํํㄹ ${ }^{23}$ a nikoli harmonické koexistence dvou vlastností či dokonce entit. Takový přístup připomíná davidsonovský anomální monismus: máme dva druhy jazyků, ale svět jako takový je jen jeden, materiální, respektive fyzikální.

Hlavní důvod, pro který Davidson upřednostňuje anomální monismus, spočívá v tom, že jinak nejsme s to dát dobrý smysl svobodnému chování spočívajícímu ve volbě mezi různými alternativami. ${ }^{24}$ Racionalita a logická koherence jsou podle něj skutečnosti, které jsou věcí mysli a nikoli materiálního výkladu světa. Davidsonův, Dennettův a tím spíš i Hř́ibkův výklad má jedno významné riziko. Hrozí, že se v podstatě srazí do precizace konceptuálního výkladu o mysli a pozapomene na fenomenální charakter vědomé zkušenosti jako takové. Co ale má být onen fenomenální charakter zkušenosti zač? Vezměme si Dennettovy pumpy na intuice z Quining Qualia ${ }^{25}$, které v každém případě cílí na nekonzistenci pojmu kvália.

Tyto intuiční pumpy podle něho vygenerovaly následující (a možná i nějaké další) vlastnosti subjektivní vědomé zkušenosti: nevyslovitelnost (ineffability), niternost (intrinsicity), soukromost (privateness) a př́mou obeznámenost (direct apprehensibility in consciousness). Před vlastní charakterizací jednotlivých vlastností je třeba předeslat, že i přes značný rozsah článku si Dennett nedává velkou práci s definicemi výše uvedených vlastností. ${ }^{26}$ To platí především pro první dvě vlast-

23 Ne náhodou najdeme v Hř́bkově knize odkaz na Sellarsovu distinkci manifestního a vědeckého obrazu, s níž pracuje i Dennett (2017) v poslední knize From Bacteria to Bach and Back: The Evolution of Minds.

24 Davidson (2001).

25 Dennett (1988).

26 To může mít dva důvody: 1) takové definice nelze uvést, protože kvália prostě neexistují, tudíž není co definovat; 2) Dennettova snaha odmítnout kvália nebude, zcela pragmaticky, vedena seriózním pokusem shromáždit co možná nejkonzistentnější charakterizaci kválií, nebot’ by tím podrýval cíle vlastního projektu. To první by nejspíš byl Dennettův explicitní postoj, to druhé možná implicitní. 
nosti, takže jsem jejich charakterizaci v zájmu jasnosti místy poněkud rozšíril při snaze zachovat ducha Dennettovy charakteristiky. Nevyslovitelnost podle tradičních zastánců kválií znamená, že bez ohledu na to, jak jsme výmluvní a kooperativní, nelze druhému sdělit o kváliích vůbec nic. Niternost je vlastnost, o níž Dennett tvrdí, že podle tradice znamená atomičnost a nemožnost kvále dále analyzovat. Zvláště tato jeho charakterizace působí poněkud nejasně. Význam pojmu niternost konotuje spíše zdůraznění toho, že kvália jsou přirozenou, esenciální vlastností zkušenosti u subjektu, který je při dané zkušenosti prožívá. Oproti tomu explikace pomocí pojmů atomičnost a nedělitelnost konotuje spíše vlastnost samotných kválií, nikoli jejich vazbu k nějakému nositeli. Bud'me však k Dennettovi vstřícní a předpokládejme, že nevhodná je pouze charakteristika v definiens, nikoli termín v definiendu. Třetí vlastností je soukromost, jež je charakterizována jakožto nemožnost interpersonálního srovnání vlastností subjektivního proživání. Poslední vlastnost představuje přímá obeznámenost (okamžitá dostupnost) ve vědomí. Kvália právě proto, že jsou niternými vlastnostmi naší zkušenosti, jsou nám př́mo přístupna ve vědomí. Kromě toho v textu někdy zaznívá i vlastnost neomylnosti (infallibility), ta ale není řazena ke čtyřem základním. Neomylnost spočívá v tom, že kvália jsou přesně taková, jak je prožíváme. Nelze se mýlit v prožívaných vlastnostech, které kvália mají, protože způsob, jak danou vědomou zkušenost subjektivně prožíváme, je esenciální vlastností této zkušenosti samotné. To je ovšem epistemická vlastnost nositele kválií a nikoli ontologická vlastnost kválií samotných.

Jinak řečeno, kvália mají být konglomerátem základních vlastností reality subjektivního prožívání. Tuto jejich charakteristiku vystihl pravděpodobně jako první Clarence I. Lewis:

„Existují rozpoznatelné kvalitativní charaktery daného [given, M.P.], které se mohou opakovat v různých zkušenostech a jsou tak svého druhu univerzáliemi. Nazývám je ,kvália‘. Avšak ačkoli jsou tato kvália univerzáliemi v tom smyslu, že jsou rozpoznávána zkušenost od zkušenosti, musí být odlišována od vlastností objekto̊. Jejich směšování je typické pro mnoho his- 
torických koncepcí stejně jako pro současné teorie. Kvále je přímo intuitivně zakoušeno, je dané, a není předmětem jakékoli možné chyby, protože je čistě subjektivní. Vlastnost nějakého objektu je objektivní; její připsání je soudem, který může být chybný; a to, co predikace tohoto soudu tvrdí, je něco, co přesahuje to, co může být dané v jakékoli singulární zkušenosti. “27

Lewisova charakterizace poměrně výstižně popisuje to, co Dennett odmítá. Podle Dennetta si nelze představit, že by existovalo něco, co by mělo všechny čtyři výše uvedené vlastnosti zároveň. ${ }^{28}$ Přesněji řečeno tvrdí, že „vědomá zkušenost nemá žádné vlastnosti, které jsou speciální v jakémkoli smyslu, v němž jsou za speciální pokládána kvália.“29

Důsledkem Dennettovy kritiky v Quining Qualia má být nutnost odmítnout kvália, tj. odmítnout kvalitativní charakter vědomí. Bez ohledu na to, že některé argumenty (intuice) se zdají být přesvědčivé více (např. ochutnávači kávy, jejichž hledání přesného obrazu kválií kolabuje na neschopnosti rozhodnout, zda jde o problém paměti, nebo hodnotících kritérií chuti kávy), jiné méně, zdá se, že Dennett spěje nevyhnutelně k jedinému závěru: vědomí nemá fenomenální charakter. Dennett nejenže tvrdí, že není konzistentní přisoudit výše uvedené čtyři vlastnosti něčemu psychicky konkrétnímu, ale ani samostatně pro něj žádná z těch vlastností není přijatelná pro charakterizaci toho, co je fenomenální aspekt vědomé zkušenosti. Pokud tedy nějaká vědomá zkušenost má vůbec existovat, musí jí Dennett přisoudit jiné vlastnosti. Nakolik mu rozumím, jeho strategie v podstatě je uchopit vědomou zkušenost se vší bezpředsudečností, která je charakteristická pro empirická zkoumání. Řídí se přitom základním pravidlem, které přijímá z tradice analytické filosofie, zejména logického behaviorismu, že má-li něco mít empirický smysl, musí to být verifikovatelné. Ovšem zprávy subjektu o jeho vlastních vědomých stavech mají empirický smysl pouze tehdy, pokud lze ověřit, zda platí, či nikoli. Tvrzení typu „právě zakouším chut’ citrónu a je to naprosto specifický prožitek, o kterém vám ale nemohu říci nic konkrétnějšího“, nelze verifikovat. Takové reporty je tudíž třeba odmítnout.

27 Lewis (1929, s. 121).

28 Dennett (1988, s. 409).

29 Tamtéž, s. 382. 
Jediná akceptovatelná tvrzení jsou ta, která lze ověřit či vyvrátit - lze o nich kupř́kladu ukázat, že subjekt se v tom, co prožíval, mýlil.

Výsledkem Dennettovy argumentace sice je uznání existence subjektivních výpovědí, jejich vědecká hodnota je však ve světle výše uvedené kritiky kválií pochybná. Vnímám jako logické, že metoda heterofenomenologie ani nemůže být ničím jiným než formální extenzí souboru empirických tvrzení o výpovědi subjektu. Tyto výpovědi jsou však pro Dennetta zajímavé pouze tehdy, pokud mají nějaké behaviorální, fyziologické či funkcionální rysy, ${ }^{30}$ které v principu umožňují jejich ověření. Protože však se subjektivními výpověd’mi o prožívané zkušenosti nelze pracovat jako s ověřitelnými fakty, je konkluzivní, že o nich Dennett hovoří jako o teoretikových fikcích. ${ }^{31}$ Pak už je jen krůček k tomu, co si lze přečíst nejen v knize The Intentional Stance, že vědomé mentální stavy máme chápat jako interpretační vehikula a instrumenty k predikci, jejichž používáním nevytváříme žádný ontologický závazek, pokud jde o stavy mysli. ${ }^{32}$ Má-li se $\mathrm{v}$ tomto př́padě jednat jen o předběžnou opatrnost a ve vědě tolik oceňovanou neutralitu, pak je vše v pořádku. Pokud však tento postoj není metodologickým stanoviskem, ale vyjadřuje koneckonců metafyzické tvrzení, že subjektivní prožívání je teoretikova fikce, pak je třeba takovýto přístup odmítnout. Obávám se, že právě to si myslí i Tomáš Hříbek, když konstatuje, že:

„Jsem totiž přesvědčen, že je [pojem fenomenálního charakteru, M.P.] ve skutečnosti bezobsažný. To má vážné důsledky pro teorii vědomí. Je-li pojem fenomenálního charakteru neudržitelný, neexistuje žádné sdílené explanandum a pro teorii je třeba najít nové východisko." ${ }^{33}$

Jak jsem již uvedl, Hř́bek v této souvislosti rozlišuje mezi deflačními a inflačními kválii. Tvrzení o prázdnosti pojmu „fenomenální charakter“ však platí pro oba typy.

Inflační kvália jsou taková, která mají ony výše uvedené čtyři vlastnosti, jako je niternost, nevyslovitelnost, soukromost a přímá obezná-

30 Dennett (2005, s. 81).

31 Dennett (1991, s. 98).

32 Dennett, (1998).

33 Hř́ibek (2017, s. 230). 
menost. Do kategorie deflačních kválií patří všechna ta pojetí, která sice respektují, že žádné entity, kterým by bylo možno konjunktivně připsat tyto čtyři vlastnosti, neexistují, přesto však kvália jsou kvalitativními vlastnostmi vědomé zkušenosti. $\mathrm{V}$ deflačním př́istupu jde podle mého soudu o to, že přinejmenším některé druhy zkušenosti, zejména percepční zkušenost, mají specifické prožívané kvalitativní vlastnosti. Tyto vlastnosti však neutvářejí nějakou samostatnou entitu, kterou bychom označili termínem kvále. Hříbkovo rozlišení inflačních a deflačních kválií je každopádně důležité ze dvou důvodů: 1) nutí obě skupiny kválofilů k tomu, aby jasně řekli, co tedy rozumí pod pojmy jako kvále, fenomenální vlastnost, kvalitativní charakter, jaké to je být, raw feel, atp.;34 2) možňuje diskutovat otázku, zda bychom přece jen nedokázali zachovat nějaké „slabšíi“ pojetí kválií.

Osobně se domnívám, že subjektivní zkušenost pravděpodobně nemá všechny výše uvedené vlastnosti zároveň. Představa entity, která je definována konjunkcí těchto vlastností, mi opravdu připadá velmi nadsazená. Nějakou slabší verzi fenomenálního charakteru - a snad ji lze pro potřeby této statě nazvat deflační - bych však rád hájil. Dokonce jsem připraven tvrdit, že fenomenální kvalita nemusí být nutně svázána s vědomím. ${ }^{35}$ Mưže existovat i jakožto nevědomá kvalita. Ze čtyř inflačních vlastností se mi jako jediná neproblematická jeví niternost, a to bez ohledu na to, zda jsou kvália vědomá, či nikoli. To, že vědomá zkušenost je vždy zkušeností nějakého subjektu, je dle mého názoru triviální fakt. Opravdu nevím, jak by musela vypadat argumentace, která by tento triviální fakt zpochybňovala. Oproti tomu nevyslovitelnost, soukromost a přímá obeznámenost se mi jeví jako v různé míře diskutabilní vlast-

34 Přiznám se, že při psaní knihy jsme dlouho debatovali, jaký pojem použít, aby nás kolegové jako Tomáš Hř́bek neoznačili za kválofily, ale abychom se zároveň nevzdali fenomenální stránky vědomí. Jako nejvíce neutrální se nám nakonec jevil pojem fenomenální charakter. Tento termín používá extenzivně například Sydney Shoemaker (1994).

35 Podrobněji viz Marvan \& Polák (2017). Teze o nevědomé fenomenální kvalitě má poměrně zajímavý potenciál, nebot’ umožňuje podpořit tvrzení, že existují situace, kdy subjekt není autoritou své fenomenální zkušenosti a jeho způsob prožívání této zkušenosti je korigovatelný. Mám na mysli Dennettovu úvahu vycházející z experimentu slepoty vůči změně (change blindness) (viz Dennett (2005, s. 82-86)). Dennett si klade otázku, zda subjekt může říci, že se mu měnila kvália pokaždé, když vnímal obraz se změnou barvy v určité části zorného pole, aniž by si této změny byl vědom. Myslím, že mohu v souladu s naší tezí o nevědomém fenomenálním charakteru tvrdit, že v případě nevědomé percepce subjekt skutečně není autoritou ohledně povahy (deflačních) kválií. 
nosti. Absence jakékoli možnosti srovnání prožívané subjektivní zkušenosti dvou lidí, která vyplývá z přijetí nevyslovitelnosti a soukromosti, posunuje subjektivní kvalitu do sféry toho, o čem se musí mlčet. Pak by ovšem bylo obtížné, nebo spíš nemožné, něco takového naturalizovat.

Tomáš Hříbek pravděpodobně správně ukazuje, že současné definice kválií jsou velmi rozdílné. Zároveň ale připouští, že společným jmenovatelem těchto vlastností je právě to, že pro nositele těchto vlastností je to být nějaké, když podstupují určitou zkušenost. „Jaké to je mít nějakou zkušenost“ je tedy ta vlastnost, již sdílí všechny Hříbkem uvedené definice deflačních kválií. Pokud mu správně rozumím, problémem je, že tato vlastnost je jednou z vlastností, jimiž byl charakterizován pojem inflačních kválií. $\mathrm{V}$ textu se mi bohužel nepodařilo nalézt, která ze čtyř vlastností by to měla být (přiznávám, že to může být moje chyba). At už to ale byla jakákoli z nich, jedná se o vlastnost, kterou jsou charakterizována inflační kvália. Pokud jsme inflační kvália odmítli, zároveň s tím jsme podle Hř́bka museli odmítnout i tyto čtyři vlastnosti. Na rozdíl od Tomáše Hř́bka si nemyslím, že nás něco podstatného nutí odmítnout všechny čtyři vlastnosti jen proto, že je pro charakterizaci dané zkušenosti nelze použít všechny zároveň. $V$ textu se snažím navrhnout zachování jedné z nich - niternosti. Je možné, že fenomenální stavy mají, kromě niternosti, vícero poměrně rozmanitých, ale rozlišitelných vlastností, tomu se zde však nelze věnovat. ${ }^{36}$

Také bych neřekl, že rozdílnost $\mathrm{v}$ definicích, a koneckonců možná i jejich nekompatibilnost, automaticky znamená, že kvalitativní charakter zkušenosti vůbec neexistuje. Bez ohledu na absenci plauzibilní definice kválií v současném diskurzu teorií vědomí není důvod tvrdit jejich neexistenci. Jde o problém nalezení korektní definice, nikoli o otázku, zda kvalitativní vlastnosti zkušenosti existují, či nikoli. Kvália (v nějakém slabším smyslu) jsou bez pochyby něco, s čím se ve vlastní zkušenosti dnes a denně prímo setkáváme. S prožitky zvuků, barev atp. máme každodenní zkušenost, a proto ani neumím dát smysl hypotéze, že fenomenální stavy ve skutečnosti neexistují.

S Dennettem a Hř́bkem bychom se pravděpodobně shodli v tom, že subjektivní zkušenost nemá všechny čtyři uvedené vlastnosti zároveň.

36 Více viz Metzinger (2008, s. 217). 
Některé vlastnosti působí z hlediska jejich možné naturalizace skutečně jako principiální překážky. Přesto se nedomnívám, že by platilo, že subjektivní zkušenost nemá žádnou z nich.

\section{Závěr}

Kdokoli, kdo nepatří do kategorie materialismu typu A (a to navíc té verze, která a priori odmítá debatu o fenomenálním charakteru), se musí vypořádat s tím, že jakákoli redukce nějakého jevu na jiný musí přesvědčivě popsat mechanismus, který bezezbytku redukuje ono redukované. Chceme-li zachovat fenomenální charakter zkušenosti, který je pro nás přirozeným způsobem, jímž svět subjektivně zakoušíme, musíme se pokusit vysvětlit, jak zapadá do materiálního světa. Toto vysvětlení jistě může mít formu redukce jednoho jevu na jiný, ale vysvětlení, jak je subjektivní zkušenost integrována do světa přírodních jevů, musí být každopádně přesvědčivé. Nezdá se, že by to $\mathrm{z}$ dennettovského tábora takovým uspokojivým vysvětlením skutečně bylo.

Pokud bychom na základě argumentu, že nic nemůže mít konjunktivně všechny čtyři uvedené vlastnosti zároveň, považovali za vyvrácené pojetí inflačních kválií, ještě to nic neř́ká o platnosti nebo neplatnosti deflačního pojetí. Ostatně i sám Tomáš Hř́bek dokázal deflační pojetí vymezit pomocí př́kladů autorů jako Owen Flanagan, Peter Carruthers, Michael Tye či Ned Block. Nezaznamenal jsem ale žádný přesvědčivý argument (nevylučuji, že jsem jej přehlédl), který by toto slabší (deflační) pojetí vyvracel. Jasnou argumentační strukturu má sice argument proti inflačním kváliím ${ }^{37}$, ten však, jak tvrdí sám autor, a já $\mathrm{s}$ ním v tomto souhlasím, není konkluzivní. „Není totiž vyloučeno, že někdo v budoucnu najde přesvědčivější způsob identifikace deflačních kválií, resp. fenomenálních charakterů. “" ${ }^{8}$ Tomáš Hříbek má nicméně za to, že poslední desetiletí výzkumu fenomenálního charakteru zkušenosti nepřinesly očekávané výsledky, pokud jde o definici tohoto pojmu. To je podle něj důvod ke ztrátě optimismu a k odmítnutí tohoto pojmu v teoriích vědomí. Jeho obavy nesdílím, byt’ asi dokážu pochopit, z čeho pramení.

37 Viz Hř́íbek (2017, s. 235).

38 Tamtéž, s. 236. 
Stejně tak si nemyslím, že tradiční teorie vědomí si mohou dovolit tento pojem opustit. To je ale téma na rozsáhlejší debatu.

Obecněji řečeno, nemyslím si, že problém fenomenálního charakteru vědomé zkušenosti lze jednoduše odstranit pouze tím, že se prokáže neudržitelnost tradičního (inflačního) chápání kválií. Stále zbývá ukázat, že ani deflační pojetí kválií nedává smysl. To, že ochutnávači kávy nejsou s to rozhodnout, zda určení charakteru kválií kolabuje na neschopnosti paměti zapamatovat si, zda dvě zkušenosti v různém čase jsou fenomenálně identické, nebo troskotá na změně hodnotících kritérií subjektu při ochutnávání kávy, anebo se hroutí díky odlišným objektivním vlastnostem kávy jako takové, přece nezpochybňuje, že při každém vědomém ochutnání kávy má jejich zkušenost nějaký vědomě zakoušený subjektivní charakter. Tvrdit opak by znamenalo, že ochutnávači kávy vykonávají svoji práci bez vědomého prožitku odlišujícího např. nežádoucí gumovou chut' kávy od žádané chuti anýzu.

Je bezesporu skvělé, že český čtenář má k dispozici rozsáhlou a koncizní monografii o filosofii vědomí. Osobně se musím přiznat, že mne zaujal organický výklad a s řadou Hř́bkových názorů se dokážu ztotožnit. Můj postoj k výše uvedeným Dennettovým argumentům však nezměnila, spíše naopak. Utvrdila mě v tom, že psychologický rozměr Dennettových úvah o fenomenálním vědomí je čistě konceptuální záležitostí a zřejmě opravdu nemá žádný fenomenální rozměr. Na Hříbkově analýze je cenné, že dotváří obraz Dennetta jako naturalistického materialisty, který odmítá úvahy o fenomenálním charakteru. Těmto naturalistickým snahám lze fandit do té míry, do jaké Dennett kritizuje tradiční (inflační) zastánce kválií, kteří konstituují kvále jako ontologickou entitu se specifickými subjektivními vlastnostmi. Taková kvália bezpochyby nikdo nikde neviděl. Ovšem odmítnout i deflační přístup, který vnímá kvále spíše jako vlastnost, či soubor vlastností, se jeví jako eliminace naší prožívané zkušenosti a nikoli její naturalizovaná redukce.

\section{Literatura}

Block, N. \& Stalnaker, R. (1999): „Conceptual Analysis, Dualism, and the Explanatory Gap.“ Philosophical Review 108 (1): 1-46. 
Chalmers, D. (2000): „What Is a Neural Correlate of Consciousness?“ In Neural Correlates of Consciousness: Conceptual and Empirical Questions, ed. T. Metzinger, MIT Press, Cambridge, MA, 2000, s. 17-39.

Chalmers, D. (2010): The Character of Consciousness. Oxford University Press, Oxford.

Churchland, P. M. (1981): „Eliminative Materialism and the Propositional Attitudes." The Journal of Philosophy 78 (2): 67-90.

Dennett, D. (1998): The Intentional Stance. MIT Press, Cambridge, MA.

Dennett, D. (2017): From Bacteria to Bach and Back: The Evolution of Minds. Allen Lane, London.

Dennett, D. (1988): „Quining Qualia.“ In Readings in Philosophy and Cognitive Science, ed. A. Goldman, MIT Press, Cambridge, MA, 1993, s. 381-414.

Dennett, D. (1991): Consciousness Explained. Penguin Books, London.

Dennett, D. (2005): Sweet Dreams. MIT Press, Cambridge, MA.

Feigl, H. (1958): „The „Mental' and the „Physical'.“ In Concepts, Theories and the Mind-Body Problem, Minnesota Studies in the Philosophy of Science, volume 2, eds. H. Feigl, M. Scriven \& M. Grover, University of Minnesota Press, Minneapolis, 1958, s. 370-497.

Feyerabend, P. (1963): „Mental Events and the Brain.“ The Journal of Philosophy 40: 295-6.

Fink, S. B. (2016): „A Deeper Look at the ,Neural Correlate of Consciousness'." Frontiers in Psychology 7: 1-13.

Frith, Ch., Perry, R. \& Lumer, E. (1999): „The Neural Correlates of Conscious Experience: An Experimental Framework." Trends in Cognitive Sciences 3 (3): 105-114.

Hohwy, J. \& Bayne, T. (2015): „The Neural correlates of Consciousness: 
Causes, Confounds and Constituents." In The Constitution of Phenomenal Consciousness: Toward a Science and Theory, ed.

S. Miller, John Benjamins, Amsterdam, 2015, s. 155-176.

Hříbek, T. (2017): Jaké to je, nebo o čem to je? Místo vědomí v materiálním světě. Filosofia, Praha.

Koch, Ch., Massimini, M., Boly, M., \& Tononi, G. (2016): „Neural Correlates of Consciousness: Progress and Problems.“ Nature Reviews 17: $307-321$.

Lewis, C. I. (1929): Mind and the World Order. Scribner's, New York.

Lewis, D. (1966): „An Argument for the Identity Theory.“ The Journal of Philosophy 63 (1): 17-25.

Lycan, W. G. (1996): Consciousness and Experience. MIT Press, Cambridge, MA.

Marvan, T. \& Polák, M. (2017): „Unitary and Dual Models of Phenomenal Consciousness." Consciousness and Cognition 56: 1-12.

Marvan, T. \& Polák, M. (2015): Vědomí a jeho teorie. Pavel Mervart, Praha.

Metzinger, T. (2008): „Empirical perspectives from the self-model theory of subjectivity: a brief summary with examples." Progress in Brain Research 168: 215-245.

Place, U. T. (1956): „Is Consciousness a Brain Process?“ British Journal of Psychology 47 (1): 44-50.

Quine, W.V.O. (1960): Word and Object. MIT Press, Cambridge, MA.

Rey, G. (1983): „A Reason for Doubting the Existence of Consciousness.“ In Consciousness and Self-Regulation, Vol. 3, eds. R. Davidson, G. Schwartz \& D. Shapiro, Plenum, New York, 1984, s. 1-39.

Rosenthal, D. M. (1997): „A Theory of Consciousness.“ In The Nature of Consciousness, eds. N. Block, O. Flanagan \& G. Güzeldere, MIT Press, Cambridge, MA, 1997, s. 729-754. 
Shoemaker, S. (1994): „Phenomenal Character.“ Noûs 28 (1): 21-38.

Smart, J. J. C. (1959): „Sensations and Brain Processes.“ The Philosophical Review 68 (2): 141-156.

Tye, M. (1995): Ten Problems of Consciousness: A Representational Theory of the Phenomenal Mind. MIT Press, Cambridge, MA.

\begin{abstract}
It Is About Phenomenal Character

Tomáš Hř́bek's arguments against the phenomenal character are based mainly on Dennett's beliefs. Dennett's long-preferred strategy in dealing with this problem is methodological naturalism. This approach has certainly bore its fruits, especially when it comes to opening a really critical debate on the issue of qualia. The problem of consciousness is, however, nowadays treated rather within materialistic metaphysics than within Dennett's methodological naturalism. This preference has both empirical and philosophical reasons which we considered with Tomáš Marvan in the book Védomí a jeho teorie. In view of the fact that Hříbek's monograph responds to some of the opinions from our book, I comment on these reactions and clarify our attitudes. At the same time, I make remarks to Hrribek's classification of our position within materialistic metaphysics as type-B materialism. The second part of the paper deals with the phenomenal nature of conscious experience, and attempts to argue that this hard problem cannot be overcome simply by demonstrating the unsustainability of the traditional understanding of qualia.
\end{abstract}

Polák, M. (2017): „Je to o fenomenálním charakteru.“ Filosofie dnes 9 (2): 44-59. Dostupné z www.filosofiednes.ff.uhk.cz. 